Abstracta Iranica Abstracta Iranica

Revue bibliographique pour le domaine irano-aryen

Volume 27 | 2006

Comptes rendus des publications de 2004

\title{
«Chancellerie et naissance de nouvelles écritures : la calligraphie persane ». Studia Islamica, 96 (2004), pp. 75-79.
}

Michele Bernardini

\section{(2) OpenEdition}

Journals

Édition électronique

URL : http://journals.openedition.org/abstractairanica/6157

DOI : 10.4000/abstractairanica.6157

ISSN : 1961-960X

Éditeur :

CNRS (UMR 7528 Mondes iraniens et indiens), Éditions de l'IFRI

Édition imprimée

Date de publication : 15 mai 2006

ISSN : 0240-8910

Référence électronique

Michele Bernardini, « «Chancellerie et naissance de nouvelles écritures : la calligraphie persane ».

Studia Islamica, 96 (2004), pp. 75-79. », Abstracta Iranica [En ligne], Volume 27 | 2006, document 250

mis en ligne le 02 janvier 2007, consulté le 25 septembre 2020. URL : http://journals.openedition.org/ abstractairanica/6157 ; DOI : https://doi.org/10.4000/abstractairanica.6157

Ce document a été généré automatiquement le 25 septembre 2020.

Tous droits réservés 


\section{«Chancellerie et naissance de nouvelles écritures : la calligraphie persane ». Studia Islamica, 96 (2004), pp. 75-79.}

\section{Michele Bernardini}

1 En partant du modèle de l'écriture dīvānī, inaugurée à la cour du Sultān Mehmed II vers 1480 grâce au secrétaire Sayyidī Moḥammad Monšì, F. Richard recherche des exemples de la création de nouvelles écritures dans le milieu persan. Parmi les exemples mentionnés, il souligne le cas de Yāqūt al-Musta‘șimī (m. 1299) qui passa de la cour abbaside au service du gouverneur ilkhanide Joveynī. Yāqūt aurait produit une écriture "nasH $\vec{\imath}$ " proche du "țult.". L'A. souligne l'absence de documents qui permettraient d'étudier le véritable apport des hurūfis à la naissance d'une nouvelle écriture. Toutefois, il décrit une nouvelle écriture, apparue toujours au cours du $13^{\mathrm{e}} \mathrm{s}$., le ta līq ou écriture "suspendue" qui est attestée dans la calligraphie d'un Mehr va Moštarī de "Așșār Tabrīzī datant de 1370. L'A. s'intéresse aussi à la naissance du nastálīq qui s'impose à peu près à la même époque dans le Fārs.

INDEX

Thèmes : 5.1. Monde iranophone 


\section{AUTEURS}

MICHELE BERNARDINI

Università di Napoli « L'Orientale » 